\title{
APPROPRIATE SCOPE OF AN ENVIRONMENTAL IMPACT STATEMENT: THE INTERRELA- TIONSHIP OF IMPACTS
}

Since the National Environmental Policy Aot of 1969 (NEPA) ${ }^{1}$ became law, the environmental impact statement has emerged as an exacting yardstick of agency compliance with the Act, and an effective weapon to force the occasionally reluctant administrator into heightened awareness of his responsibilities under NEPA. Section $102(2)(C)$ of NEPA calls for preparation of an environmental impact statement to accompany all "proposals for legislation and other major Federal actions significantly affecting the quality of the human environment," ${ }^{2}$ and the federal courts, lest the environmental concerns "heralded in the halls of Congress, [be] lost or misdirected in the vast hallways of the federal bureaucracy," 3 have held consistently that NEPA creates duties enforceable in an action challenging the adequacy of such an impact statement. ${ }^{4}$ The predictable result ${ }^{5}$ has been a plethora of cases seeking judicial determinations that the impact statements prepared by agencies failed to comply with the requirements of NEPA, ${ }^{6}$ or challenging the failure to

\footnotetext{
THE FOLLOWING CITATION WILL BE USED IN THIS NOTE:

Hearings on National Environmental Policy Act Oversight Before the Subcomm. on Fisheries and Wildlife Conservation and the Environment of the House Comm. on Merchant Marine and Fisheries, 94th Cong., 1st Sess., ser. 94-14, at 8 (1975) Thereinafter cited as Hearings on NEPA Oversight].
}

1. 42 U.S.C. $\$ \$ 4331$ et seq. (1970).

2. 42 U.S.C. $\$ 4332(2)(C)(1970)$.

3. Calvert Cliffs Coordinating Comm., Inc. v. AEC, 449 F.2d 1109, 1111 (D.C. Cir. 1971).

4. See, e.g., Environmental Defense Fund, Inc. v. Corps of Engineers, 492 F.2d 1123 (5th Cir. 1974); Environmental Defense Fund, Inc. v. Corps of Engineers, 470 F.2d 289 (8th Cir.), cert. denied, 412 U.S. 931 (1972); Scenic Hudson Preservation Conference v. FPC, 453 F.2d 463 (2d Cir. 1971), cert. denied, 407 U.S. 926 (1972); Calvert Cliffs Coordinating Comm., Inc. v. AEC, 449 F.2d 1109 (D.C. Cir. 1971).

5. Cf. Calvert Cliffs Coordinating Comm., Inc. v. AEC, 449 F.2d 1109, 1111 (D.C. Cir. 1971) ("These cases are only the beginning of what promises to become a flood of new litigation"). See also Lynch, Complying with NEPA: The Tortuous Path to an Adequate Environmental Impact Statement, 14 ARIz. L. Rev. 717, 718 (1972) ("The geneses of such litigation are readily identifiable-a law couched in generalities, implemented by equally indefinite 'Guidelines,' intermingled in an atmosphere of judicial activism, agency foot-dragging and litigant zealousness").

6. E.g., Greene County Planning Bd. v. FPC, 455 F.2d 412 (2d Cir.), cert. denied, 409 U.S. 819 (1972); Committee for Nuclear Responsiblity v. Seaborg, 463 F.2d 783 (D.C. Cir.), injunction denied sub nom. Committee for Nuclear Responsibility v. Schlesinger, 404 U.S. 917 (1971). 
prepare an impact statement. ${ }^{7}$ Increasingly common is the claim that the scope of an impact statement is inappropriate-that the federal action under consideration has been artificially truncated into segments which cannot be meaningfully evaluated in isolation from one another.

To identify the appropriate unit for evaluation, the courts have utilized a variety of criteria, drawn for the most part from the paradigm situation of improper segmentation, the highway cases. ${ }^{8}$ This Note will analyze and criticize the most commonly used criteria-independent utility of a segment, irretrievable commitunent of resources, foreclosure of alternatives, and the existence of a program plan. A new analysis suggested by several recent cases, ${ }^{9}$ the interrelatedness of impacts analysis, will be discussed and expanded into a coinprehensive and inore workable approach to the problem of identifying the appropriate scope of an impact statement.

\section{The Environmental Impact Statement and the SCOPE of a "MaJor Federal Action"}

The inpact statement is crucially inportant because it is the sole action-forcing provision of NEPA: through the medium of the impact statement, decisions affecting the environment are subjected to public scrutiny ${ }^{11}$ and to judicial review. ${ }^{11}$ It is the product of distrust of the administrative process, and manifests the suspicion that without some check on regulatory decisionmaking environmental concerns would receive short shrift. ${ }^{12}$ The mandate to prepare an impact statement is (1972).

7. E.g., Hanly v. Mitchell, 460 F.2d 640 (2d Cir.), cert. denied, 409 U.S. 990

8. See, e.g., Movement Against Destruction v. Volpe, 36I F. Supp. 1360 (D.Md. I973), aff'd per curiam, 500 F.2d 29 (1974); James River and Kanawha Canal Parks, Inc. v. Richmond Metropolitan Authority, 359 F. Supp. 611 (E.D. Va. 1973); Citizens for Mass Transit Against Freeways v. Brinegar, 357 F. Supp. 1269 (D. Ariz. 1973); Daly v. Volpe, 350 F. Supp. 252 (W.D. Wash. 1972), injunction dissolved, 376 F. Supp. 987 (1974), aff'd, 514 F.2d 1106 (9th Cir. 1975); Thompson v. Fugate, 347 F. Supp. 120 (E.D. Va. 1972).

9. Ecology Center of La., Inc. v. Coleman, 515 F.2d 860 (5th Cir. 1975) (see notes 132-34 infra and accompanying text); Appalachian Mountain Club v. Brinegar, 394 F. Supp. 105 (D.N.H. 1975) (see notes 123-26 infra and accompanying text).

10. The following statement was made by Sen. Henry Jackson (D. Wash.), sponsor of NEPA:

The basic principle of the policy is that we must strive in all that we do, to achieve a standard of excellence in man's relationships to his physical surroundings. If there are to be departures from this standard of excellence they should be exceptions to the rule and the policy. And as exceptions, they will have to be justified in the light of public scrutiny as required by section 102 . 115 CoNG. REC. 40,416 (1969).

11. See cases cited in note 4 supra.

12. Note, A Panoramic View of the National Environmental Policy Act, 16 
conditioned, however, upon the existence and dimensions of a "major federal action," ${ }^{13}$ and the panorama of federal activity is so vast that isolating an individual "action" for environmental evaluation is often difficult. The problem is compounded by the fact that some federal programs span a period of years, and may have been commenced before NEPA became effective. ${ }^{14}$ The responsible federal official is faced with determining whether to prepare one impact statement to evaluate a broad multi-year program, ${ }^{15}$ a series of statements to evaluate individual components of the program (and how many components such a broad program should be divided into), or the broader program statement as well as the component statements. ${ }^{10}$

There are pitfalls whatever decision is made. If an impact statement is prepared for the broad program only, it may give insufficient treatment to the impact of a component project, ${ }^{17}$ or may provide

HowARD L.J. 116, 123 n.16 (1970). See generally Conservation Soc'y of S. Vt., Inc. v. Secretary of Transp., 362 F. Supp. 627, 637 (D. Vt. 1973), aff'd, 508 F.2d 927 (2d Cir. 1974), vacated sub nom. Coleman v. Conservation Soc'y of S. Vt., Inc., 96 S. Ct. 19 (1975), rev'd, 531 F.2d 637 (2d Cir. 1976) (alluding to the possible inconsistency of the existence of highway trust funds with NEPA); LIBRARY OF CONGRESS, A NATIONAL POLICY FOR THE ENVIRONMENT, SELECTED EXCERPTS FROM THE CONGRESSIONAL RECORD and Congressional Documents 32 (1969) (comment of Sen. Muskie): "The concept of self policing by Federal Agencies which pollute or license pollution is contrary to the philosophy and intent of existing environmental quality legisiation . . . ."

13. 42 U.S.C. $\$ 4332$ (2)(C) (1970).

14. The average time from concept to conclusion of a Corps of Engineers project is 15-16 years. Hearings on NEPA Oversight 8. The highway challenged in Named Individual Members of the San Antonio Conservation Soc'y v. Texas Highway Dep't, 446 F.2d 1013 (5th Cir.), cert. denied, 403 U.S. 932 (1971), was originally proposed in 1955. The route was chosen in 1960, and suit was brought in 1967. Id. at 1014-16. The Strawberry Aqueduct system, the impact statement for which was challenged in Sierra Club v. Stamm, 507 F.2d 788 (10th Cir. 1974), is part of a water collection system which will probably not be completed until sometime in the next century. Id. at 789 . The breeder reactor program, subject of Scientists' Institute for Public Information, Inc. v. AEC, 481 F.2d 1079 (D.C. Cir. 1973), will not result in a commercially conpetitive reactor until 2010. S BNA Environmental Rep. CuRrent Developments 1801 (Mar. 14, 1975). Perhaps the project of greatest antiquity was the Tennessee-Tombigbee Waterway, considered in Environmental Defense Fund, Inc. v. Corps of Engineers, 492 F.2d 1123 (5th Cir. 1974), which was originally studied in 1874-75. Id. at 1127 .

15. Throughout this Note, the term "program" will signify a set of individual actions related by a single purpose or design, while the term "project" will refer to a narrow segment or component of a broader program.

16. In fact, it may be questionable whether any federal program exists at all. See, e.g., Sierra Club v. Morton, 514 F.2d 856 (D.C. Cir. 1975), cert. granted sub nom. Kleppe v. Sierra Club, 96 S. Ct. 772 (1976).

17. A program statement on the use of herbicides in the national forests was found inadequate by two courts for failure to include discussion of specific sites and individual geographic conditions. Kelley v. Butz, 8 E.R.C. 1449 (W.D. Mich. 1975); Wisconsin v. Butz, 7 E.R.C. 1651 (E.D. Wis. 1975). Sce also Natural Resources Defense Council, 
inadequate notice to persons affected by individual projects, thus foreclosing the possibility of obtaining their comments and suggestions on the program. ${ }^{18}$ If the decision is made to segment the program and evaluate each project individually, a project inipact statement niay overlook effects of the project beyond its immediate vicinity; ${ }^{19}$ there may be a failure to consider the cumulative effects of a series of individual projects, ${ }^{20}$ or completion of one or more projects inay force completion of the final project which may itself have a detrimental impact. ${ }^{21}$ Also involved in the decision is the desire to avoid the considerable expense of preparing unnecessary impact statements ${ }^{22}$ and the countervailing fear of expensive delays incident to litigation over the scope of the statement prepared. ${ }^{23}$

Final review of every impact statement prepared by a federal official and pronulgation of guidelines for statement preparation are the

Inc. v. Morton, 388 F. Supp. 829 (D.D.C. 1974); Natural Resources Defense Council, Inc. v. TVA, 367 F. Supp. 122 (E.D. Tenn. 1973), aff'd, 502 F.2d 852 (6th Cir. 1974).

18. See, e.g., letter from Hamilton Hess, Northern California Regional Conservation Comm., Sierra Club, to Dep't of the Interior, Nov. 10, 1971, in DEP'T OF THE INTERIOR, Final Environmental Statement for the Geothermal Leasing Program ch. I, at 436 (1973).

19. See, e.g., Atchison T. \& S.F. Ry. v. Callaway, 382 F. Supp. 610 (D.D.C. 1974); Committee to Stop Route 7 v. Volpe, 346 F. Supp. 731 (D. Conn. 1972), extension of injunction denied sub nom. Citizens for Balanced Environment and Transp. v. Volpe, 376 F. Supp. 806 (D. Conn.), aff'd, 503 F.2d 601 (2d Cir. 1974), cert. denied, 96 S. Ct. 135 (1975).

20. See, e.g., Sierra Club v. Morton, 514 F.2d 856 (D.C. Cir. 1975), cert. granted sub nom. Kleppe v. Sierra Club, 96 S. Ct. 772 (1976); Conservation Soc'y of S. Vt., Inc. v. Secretary of Transp., 508 F.2d 927 (2d Cir. 1974), vacated sub nom. Coleman v. Conservation Soc'y of S. Vt., Inc., 96 S. Ct. 19 (1975), rev'd, 531 F.2d 637 (2d Cir. 1976).

21. Sec, e.g., Named Individual Members of the San Antonio Conservation Soc'y v. Tcxas Highway Dep't, 446 F.2d 1013 (Sth Cir.), cert. denied, 403 U.S. 932 (1971); Appalachian Mountain Club v. Brinegar, 394 F. Supp. 105 (D.N.H. 1975).

22. Impact statements can run to incredible lengths, such as the 2,485 page document challenged in Inman Park Restoration, Inc. v. Urban Mass Transp. Administration, Civil No. 75-717A (N.D. Ga. Nov. 7, 1975), or the 4,300 page statement prepared for the liquid metal breeder reactor program. 5 BNA ENVIRONMENTAL REP. CURRENT DEVELOPMENTS 1617 (Feb. 14, 1975). The cost of preparing an EIS can be equally astronomical. According to Angelo Giambusso, a member of the Nuclear Regulatory Commission, the average cost of an impact statement covering a license for a nuclear reactor is $\$ 1.7$ million. 6 BNA Environmental ReP. Current DeVElopments 205, 206 (May 23, 1975). The Corps of Engineers has added 215 full-time employees and 300 part-time employees to handle impact statement preparation and review, Hearings on NEPA Oversight 22, and in fiscal year 1974 devoted $\$ 22$ million to the process. Sixth ANnuAl Report of the Council on Environmental Quality 636 (1975).

23. In some cases the cost of environmental study or litigation is considerable: "[I]t is estimated that the cost of replacing the lost capacity of the Palisades plant in Michigan is $\$ 1$ million per month, while that of New York's Indian Point 2 plant is put at 
responsibility of the Council on Environmental Quality (CEQ).$^{24}$ Since its publication of early directives on impact statement preparation, the CEQ has "strongly encouraged" 25 the use of broad program statements, and the current Guidelines call for evaluation of a broad program whenever possible:

In many cases, broad program statements will be required in order to assess the environmental effects of a number of individual actions on a given geographical area (e.g., coal leases), or environmental impacts that are generic or common to a series of agency actions (e.g., maintenance or waste handling practices), or the overall impact of a large scale program or chain of contemplated projects (e.g., major lengths of highway as opposed to small segments). Subsequent statements on major individual actions will be necessary where such actions have significant environmental impacts not adequately evaluated in the program statement. ${ }^{28}$

CEQ officials perceive a need for more program statements ${ }^{27}$ and are currently developing guidehnes to assist agencies in defining the appropriate scope of the impact statements prepared. ${ }^{28}$ Numerous commentators have echoed the CEQ position, ${ }^{20}$ calling for program statements in

$\$ 3$ million per month." Murphy, The National Environmental Policy Act and the Licensing Process: Environmentalist Magna Carta or Agency Coup de Grace?, 72 Colum. L. Rev. 963, 969 (1972). The cost of delay in construction of the Storm King project at Cornwall, N.Y., challenged in Scenic Hudson Preservation Conference v. FPC, 453 F.2d 463 (2d Cir. 1971), cert. denied, 407 U.S. 926 (1972), according to the Chairman of the Board of the Consolidated Edison Co., was the New York power shortage of 1969. Luce, Power for Tomorrow: The Siting Dilemma, 1 ENv. LAw 60 (1970).

24. 42 U.S.C. $\$ \S 4332(2)(C), 4344(3)$ (1970); Exec. Order No. 11,514, 3 C.F.R. 271 (1974).

25. Sixtm Annual Report of the Council on Environmental QualtTy 640-41 (1975); FIFTH ANNUAL RePORT OF THE COUNCIL ON ENVIRONMENTAL QUALITY 392-93 (1974); THIrd ANNuAl Report of the Council on ENVIRoNmental QualtT 233 (1972); Council on Environmental Quality, Memorandum to Federal Agencies on Procedures for Improving Environmental Impact Statements, 3 BNA ENVIRONMENTAL ReP. CURRENT DeVElopMents 82, 87 (May 19, 1972).

26. 40 C.F.R. $\$ 1500.6(d)(1)(1974)$.

27. Fifth ANNual Report of the Council on Environmental Quadity 392-93 (1974); statement of Malcolm F. Baldwin, Senior Staff Member, CEQ, in 6 BNA ENVIRonmental Rep. Current Developments 205 (May 23, 1975).

28. Hearings on NEPA Oversight 206 (statement of Russell W. Peterson, Chairman, Council on Environmental Quality).

29. See, e.g., Coggins, Some Suggestions for Future Plaintiffs on Extending the Scope of the National Environmental Policy Act, 24 U. KAN. L. REv. 307 (1976); Comment, Planning Level and Program Impact Statements Under the National Environmental Policy Act: A Definitional Approach, 23 U.C.L.A.L. REv. 124 (1975); Note, Project-Program Relationships Used to Define Applicable Scope of Section 102(2)(C) of NEPA, 23 U. KAN. L. REV. 342 (1975). 
such diverse fields as atomic energy, ${ }^{30}$ sewage facilities, ${ }^{31}$ low-cost housing, ${ }^{32}$ and highway planning. ${ }^{33}$

In deciding upon a challenge to the scope of an impact statement, a court is faced with a fait accompli-the judge must decide not upon the desirability of an impact statement of different scope, but the adequacy of the analysis given the unit selected by the responsible official. This decision is based on a series of inquiries. If the impact statement was prepared upon an individual project, is a program statement necessary for adequate evaluation? Will one program statement suffice, or are both a program statement and a project statement necessary? If a program statement is mandated, should it be prepared immediately, or must planners await future developments before meaningful analysis can proceed? Finally, should the challenged project be halted pending environmental evaluation of the program of which it is a part? To answer these questions, the courts have utilized several criteria, which will now be considered.

\section{Currently Used Criteria: An Inadequate Focus}

Even before NEPA becaine law, challenges to the scope of project evaluation were raised under section $4(f)$ of the Department of Transportation Act, ${ }^{3+}$ which prohibits the Secretary of Transportation from approving highway segments which pass through park lands unless he has determined that there is no feasible and prudent alternative. In one such case, Named Individual Members of the San Antonio Conservation Society v. Texas Highway Department, ${ }^{35}$ an expressway had been divided into three segments, with the middle one passing through park lands. The Court of Appeals for the Fifth Circuit expressly disapproved of such segmentation, pointing out that construction of the two end segments would "make destruction of further parklands inevitable."36 The significance of San Antonio Conservation Society was the court's recognition that the segmentation adopted would severely circumscribe, if not eliminate, the alternatives to construction of the final segment through the park lands. ${ }^{37}$

30. See Murphy, supra note 23 , at $988-89$.

31. See Comment, Four Years of Environmental Impact Statements: A Review of Agency Administration of NEPA, 8 AKRoN L. REv. 545, 561 (1975).

32. See Ackerman, Impact Statements and Low Cost Housing, 46 S. CAL. L. REv. 754, 795-99 (1973).

33. See Comment, Environmental Analysis and Reporting in Highway System Planining, 121 U. PA. L. REv. 875 (1973).

34. 49 U.S.C. $\$ 1653(f)$ (1970).

35. 446 F.2d 1013 (5th Cir.), cert. denied, 403 U.S. 932 (1971).

36. 446 F.2d at 1023 .

37. Accord, Citizens Comm. for the Hudson Valley v. Volpe, 302 F. Supp. 1083 
Segmentation of highway programs as in San Antonio Conservation Society, far from being atypical, seems to be endemic. ${ }^{38}$ To counteract the tendency towards piecemeal analysis, and in response to a number of statutory mandates, ${ }^{39}$ the Federal Highway Administration revised Policy and Procedures Memorandum (PPM) $90-1^{40}$ by promulgating new regulations which mandated environmental evaluation of a highway section "as long as practicable to permit consideration of environmental matters on a broad scope."11 A highway section, in turn, was defined as "a substantial length of highway between logical termini." 42

The Eighth Circuit drew heavily upon PPM 90-1 when faced with a challenge to an impact statement prepared for a section of freeway in Indian Lookout Alliance v. Volpe. ${ }^{43}$ Interpreting PPM 90-1 to require the independent utility of a highway section when isolated from the remainder of the program, the court held that the section was inappropriate-not ending in major termini, it could have no independent utility. ${ }^{44}$ The guidelines of PPM 90-1 and the independent utility

(S.D.N.Y. 1969). In Citizens Committee the Corps of Engineers was planning construction of a freeway along the Hudson River, which would require construction of both a dike and a causeway. The court held that the Corps would have to obtain approval for both the dike and the causeway before construction of either could begin. If the dike were already constructed, the Secretary of Transportation would be limited in the alternatives he could consider under section $4(f)$ of the DOT Act, 49 U.S.C. $\$ 1653(f)$ (1970).

38. See, e.g., Citizens to Preserve Overton Park v. Volpe, 401 U.S. 402 (1971); Daly v. Volpe, 514 F.2d 1106 (9th Cir. 1975); Ecology Center of La., Inc. v. Coleman, 515 F.2d 860 (5th Cir. 1975); Swain v. Brinegar, 517 F.2d 766 (7th Cir. 1975).

The tendency to divide highways into sections has been ascribed to the long-range planning process, which proceeds from comprehensive system-wide analysis to an increasingly detailed design focusing on a single section of highway, and to the funding process, by which funds must be used within two years of appropriation and only for the particular project for which they are earmarked. See Comment, supra note 33, at 877, 880-81; Note, Federal-Aid Highway Construction and the National Environmental Policy Act of 1969, 3 N.Y.U. Rev. L. \& Soclal Change 11, 19-20 (1973).

It has been suggested that the Department of Transportation has become more responsive to the need for broader program statements, Hearings on NEPA Oversight 54, as evidenced by the decreasing number of impact statements filed for highway projects. Id. at 211.

39. Section 106 of the Historic Preservation Act of 1966, 16 U.S.C. $\$ 470$ (f) (1970); section 309 of the Clean Air Act of 1970, 42 U.S.C. $\$ 1857 \mathrm{~h}-7$ (1970); NEPA, 42 U.S.C. $\$ \S 4331$ et seq.; section $4(f)$ of the DOT Act, 40 U.S.C. $\$ 1653(f)$ (1970).

40. 39 Fed. Reg. 41,804 (1974). The revisions are embodied in 23 C.F.R. Part 771 (1975).

41. 23 C.F.R. $\$ 771.5$ (a) (1975).

42. 23 C.F.R. $\$ 771.3(\mathrm{~g})(1975)$.

43. 484 F.2d 11 (8th Cir. 1973).

44. $I d$. at 19. 
analysis of Indian Lookout Alliance have continued to dominate the judicial response to environmental litigation over highway segments. ${ }^{45}$

As environmentalists challenged an increasing number and variety of project impact statements, the courts turned to the highway precedents for principles to identify the appropriate scope for an impact statement, in the belief that the independent utility criterion could be applied readily outside the highway context. ${ }^{4 B}$ The apparent simplicity of this criterion proved somewhat deceptive, however, as may be seen in Sierra Club v. Callaway ${ }^{47}$ (Wallisville Dam), wherein the Fifth Circuit reversed a lower court holding that the Wallisville Dam project, a dam and reservoir on the Trinity River in Texas, had been improperly segmented froin the Trinity River navigation and flood control program. While affirming the finding that the impact statement was inadequate in other respects, ${ }^{48}$ the Fifth Circuit specifically disapproved of the district court's decision that the project had been improperly segmented from the Trinity system. ${ }^{40}$ Pointing out that Congress had rehed upon the local purposes of the Wallisville Dam in the appropriations process, the court held that the evidence adequately established the local utility of the project, and the dain was viewed as a separate viable entity. ${ }^{50}$

One of two lessons may be drawn from Wallisville Dam: either the independent utility criterion is so ambiguous that it is impossible to predict how a court will apply it, or the Fifth Circuit has defined independent utility so broadly that a project impact statement seldom will be held to be improperly segmented..$^{51}$ The accuracy of the second conclusion, that most project statements will be sustained under the independent utility criterion, is suggested by the results in subsequent cases.

The Tenth Circuit, in Sierra Club v. Stamm, ${ }^{52}$ found adequate an

45. In 1975, the Ninth Circuit in Daly v. Volpe, 514 F.2d 1106 (9th Cir. 1975), while acknowledging an element of arbitrariness in selection of the termini mentioned in the regulations, found the challenged segmentation justified by the PPM criteria and the independent local utility of the segment. Id. at 1110-11. The Department of Transportation continues to utilize the independent utility criterion to determine the scope of an impact statement. Hearings on NEPA Oversight 54.

46. See, e.g., Citizens Against the Destruction of Napa v. Lynn, 391 F. Supp. 1188, 1193 (N.D. Cal. 1975) ("The soundest approach to the highway cases in a non-highway context is to extract the common sense tests the courts in those cases employed").

47. Sierra Club v. Froehlke, 359 F. Supp. 1289 (S.D. Tex. 1973), modified sub nom. Sierra Club v. Callaway, 499 F.2d 982 (5th Cir. 1974).

48. 499 F.2d at 994 .

49. Id. at 993.

50. Id. at 988-90.

51. Cf. Comment, supra note 29 , at 144-46.

52. 507 F.2d 788 (10th Cir. 1974). 
impact statement prepared for the Strawberry Aqueduct project, despite the fact that it was only one component of the Bonneville Unit water collection system. The Bonneville system, in turn, was only one of six components of the larger Central Utah Project. Finding that the Strawberry Aqueduct project could function independently of the remaining unconstructed systems and that it was not so intertwined with the larger program as to be a mere component, the Tenth Circuit held that the project liad independent utility and that accordingly no further environniental evaluation was necessary. ${ }^{53}$ The opinion lacks an adequate factual description of the project to permit proper evaluation of the decision, but some degree of independent utility can be attributed to nost public works projects.

A more troubling result was reached by the Nintli Circuit in Trout Unlimited $v$. Morton, ${ }^{54}$ in which environmental groups challenged an impact statement prepared for the first of two phases of the Teton Basin Project. The first phase consisted of construction of a dam and reservoir and disposition of the first half of the irrigation water made available by the project, while the second phase consisted of disposition of the remainder of the irrigation water. Asking whether there was sucl a dependency between the two phases that it would be irrational or unwise "to undertake the first phase if subsequent phases were not also undertaken," "5. the court answered that the first phase was feasible whether or not the second phase was launched. ${ }^{50}$ While the court's finding of independent utility of the first phase nuay be correct, this cannot be said of the second phase, which was absolutely inpossible without construction of the dain.

The generic problem presented by Trout Unlimited is that of excess capacity-an initial project, ostensibly with independent utility, is designed to be compatible witl later projects. Together, the projects form a system witl considerably broader uses and impacts than originally asserted for the first project. Illustrative of this problem was the proposed reconstruction of Locks and Dam 26, enjoined in Atchison, Topeka \& Santa Fe Railway v. Callaway. ${ }^{57}$ Part of the navigational systen on the upper Mississippi River, Locks and Dam 26, was to be rebuilt and increased in capacity. The impact statement prepared for the

53. Id. at 791 .

54. 509 F.2d 1276 (9th Cir. 1974).

55. Id. at 1285 .

56. Id.; accord, Sierra Club v. Froehlke, 392 F. Supp. 130 (E.D. Mo. 1975); Environmental Defense Fund, Inc. v. Armstrong, 356 F. Supp. 131 (N.D. Cal.), aff'd, 487 F.2d 814 (9th Cir. 1973).

57. 382 F. Supp. 613 (D.D.C. 1974). 
project was challenged on the ground that it was the first step in a multibillion dollar, systemwide program to expand the system to accommodate larger barges and increase river traffic. Rejecting the argument that the independent utility of the project rendered further evaluation unnecessary, the court held that systemwide evaluation was required before the project could proceed. ${ }^{58}$ Atchison, Topeka \& Santa Fe graphically illustrates a serious defect of the imdependent utility criterion. While use of the step-by-step approach adopted by the Corps of Engineers in studying Locks and Dam 26 makes possible the fragmented analysis of independent projects, the comprehensive system of which the projects are a part may escape environinental evaluation altogether, or at best may be studied too late for serious consideration of alternatives.

A further criticism of the independent utility criterion is its difficulty of application. Unless the concept is construed as broadly as it was in Wallisville Dam, it is extremely difficult to quantify the benefits derived from a project, categorize them as local or systemwide, and balance the purely local benefits against the wider benefits. ${ }^{59}$ There is an element of arbitrariness in such categorization, as there may be in definition of the scope of the project itself, ${ }^{00}$ which lends itself to the possibility of manipulation of project scope and benefits to ensure project approval. ${ }^{.1}$ The nost devastating criticism of the independent utility criterion, however, is that satisfaction of the criterion is not sufficient to ensure that the environmental impact of a project has been adequately analyzed. To demonstrate why this is so, it is necessary to

58. Id. at 621.

59. See Citizens Against the Destruction of Napa v. Lynn, 391 F. Supp. 1188, 1194 (N.D. Cal. 1975) ("[The independent utility criterion] is an exceedingly difficult test to carry over to the instant facts").

60. Daly v. Volpe, 514 F.2d 1106, 1110 (9th Cir. 1975). The arbitrariness of dividing the Teton Basin Project into two phases, see text accompanying notes 54-56 supra, is patent.

61. See Named Individual Members of the San Antonio Conservation Soc'y v. Texas Highway Dep't, 446 F.2d 1013 (Sth Cir.), cert. denied, 403 U.S. 932 (1971); Appalachian Mountain Club v. Brinegar, 394 F. Supp. 105, 115 (D.N.H. 1975):

I-93 has become a classic example of segmentation. By proposing uncontroversial segments of the highway, one per [impact statement], and leaving the most controversial seginent for last, the FHWA is able to 'build' a case, by constructing the bulk of an interstate system, for the completion of construction of the final segment of the system. In this case, that last segment will be Franconia Notch, which is a major environmental issue in New England . Sec generally Conservation Soc'y of S. Vt., 1nc. v. Secretary of Transp., 508 F.2d 927, 935 (2d Cir. 1974), vacated sub nom. Coleman v. Conservation Soc'y of S. Vt., Inc., 96 S. Ct. 19 (1975), rev'd, 531 F.2d 637 (2d Cir. 1976), in which the court pointed out that even if a highway segment had independent utility, the regulations still call for an impact statement on as long a segment as practicablc. See note 41 supra. 
consider two additional criteria-the irreversible and irretrievable commitment of resources to a project, and the foreclosure of alternatives to the action.

\section{Commitment of Resources AND FORECLOSURE OF ALTERNATIVES}

NEPA mandates that the impact statement include consideration of "alternatives to the proposed action," trievable commitments of resources which would be involved in the proposed action should it be implemented." ${ }^{63}$ As courts examined the appropriate scope of an impact statement, these two factors were gradually adopted as criteria to guide their inquiry. Under the criterion of foreclosure of alternatives, the project evaluated in the impact statement is too narrow if completion of the project will foreclose the possibility of various alternatives for subsequent projects within the program. According to the commitment-of-resources criterion, if completion of a project entails an irreversible and irretrievable commitment of resources to completion of the program as a whole, the entire program must be evaluated before approval of the project.

The Court of Appeals for the District of Columbia Circuit gave careful consideration to these two criteria in the landmark case of Scientists' Institute for Public Information, Inc. v. Atomic Energy Commission $^{64}$ (SIPI), which has been called the "leading case analyzing NEPA's 'irreversible commitment' language." Rejecting the AEC's claim that its long-range Liquid Metal Fast Breeder Reactor (LMFBR) program $^{66}$ could be adequately evaluated in statements for individual facilities, the court ordered preparation of an impact statement for the overall program. The court alluded to the massive capital investment necessary for the program, and pointed out that this irretrievable commitment of resources tended to shift the balance of environmental and economic costs and benefits in favor of completion of the program. ${ }^{67}$ Moreover, by virtue of the long lead times involved in modern technological research, the choice of developing one application was seen as inevitably precluding development of others. ${ }^{68}$ Through this commit-

62. 42 U.S.C. $\$ 4332$ (2)(C) (iii) (1970).

63. Id. $\$ 4332(2)(\mathrm{C})(\mathrm{v})(1970)$.

64. 481 F.2d 1079 (D.C. Cir. 1973).

65. Friends of the Earth v. Coleman, 513 F.2d 295, 299 (9th Cir. 1975).

66. The LMFBR program is described in SIPI, $481 \mathrm{~F} .2 \mathrm{~d}$ at 1082-84.

67. Id. at 1090 . The court also pointed out that as government sponsored technology matures, vested interests begin to develop in implementation of the technology. Id. at 1089 n.43.

68. "The manner in which we divide our limited research and development dollars 
ment of resources and foreclosure of alternatives, concluded the court, the program as a whole has an effect on the environment apart from its component parts, and an impact statement must therefore be prepared for the program itself. ${ }^{09}$

SIPI is one of the few cases in which there was a truly absolute foreclosure of alternatives. Given the time and capital necessary to develop the technology for a commercially feasible method of generating power, the choices made in 1976 will indeed determine the type of technology available in $1995 .^{70}$ More commonly, however, completion of a contemplated project will not render alternatives to the broader program absolutely impossible; rather, such alternatives may become highly unlikely. ${ }^{71}$ Typical of such cases was the proposed construction of two end segments of an expressway up to the opposite sides of park lands, a segmentation rejected by the Fifth Circuit in San Antonio Conservation Society. ${ }^{72}$ Construction of the end segments would not have rendered impossible an alternative location for the entire expressway, but it was highly unlikely that the segments would be entirely abandoned and a new expressway constructed. ${ }^{73}$ Foreclosure of alternatives, accordingly, rather than a umitary criterion or test, is a sliding scale, on which the project may range from improbable to absolutely impossible. ${ }^{74}$

today among various promising technologies in effect determines what technologies will be available, and what type and amount of environmental effects will have to be endured, in the future when we must apply some new technology to meet projected energy demand." Id. at 1090.

69. Id. at 1090-91. Before ordering preparation of an impact statement, the court considered the ripeness of the program for environmental evaluation. See note 135 infra and accompanying text.

70. For example, the Energy Research and Development Administration has budgeted more money for the development of the LMFBR, which is not expected to become commercially available until 1990 , than for all other energy alternatives combined. 5 BNA Environmental Rep. Current Developments 1801 (Mar. 14, 1975). Cf. SIPI, 48I F.2d at 1090.

71. See Friends of the Earth v. Coleman, 513 F.2d 295, 300 (9th Cir. 1975) (completion of early project will "most likely determine" location of later project); No East-West Highway Comm. v. Whitaker, 403 F. Supp. 260, 270 (D.N.H. 1975) (It is "highly probable" that completion of initial phases of program "will have a coercive effect on further highway construction. . ."). See note 74 infra.

72. 446 F.2d 1013 (5th Cir.), cert. denied, 403 U.S. 932 (1971). See notes 35-37 supra and accompanying text.

73. Moreover, even if alternatives were not absolutely preciuded, there was present an irretrievable and irreversible commitment of resources to the program.

74. The degree of foreclosure of alternatives determines the position of a project upon this sliding scale, as may be seen in Friends of the Earth v. Coleman, 513 F.2d 295 (9th Cir. 1975). Environmentalists in that case challenged the decision of state highway officials, who were planuing a segment of interstate highway, to obtain the fill 
Commitment of resources to the more expansive breeder reactor program in the SIPI case involved a corollary foreclosure of alternative approaches to development of new energy technology. Recognizing the relationship between these two criteria, most courts have applied them together. These courts, however, have overlooked the relationship between the commitment of resources involved in a project and the independent utility of the project. If a project has no independent utility of its own, all resources devoted to the project will be lost unless the entire program of which it is a part is completed, thus effectively creating an irreversible and irretrievable commitment of resources to completion of the program. In SIPI, development of the technology for the reactors liad no utility unless the program was completed through the construction of sucli reactors on a commercial basis, and thus there was an irretrievable commitment of resources. Likewise, there was an absolute foreclosure of alternatives to the program. ${ }^{75}$

In contrast, if a project does liave an independent utility apart from the broader program of which it is a part, its completion does not in reality constitute a commitment of resources to the broader programthe resources dedicated or "sunk into" the project are productively einployed whatever decision is made concerning the broader program, and their commitment is neither irreversible nor irretrievable. ${ }^{76}$

needed for the highway from the site of a proposed canal. The environmentalists claimed that the fill excavations would foreclose alternatives to construction of the canal. Acknowledging that if the canal were built, the excavations would "most likely" determine the course of the canal, the Ninth Circuit nevertheless pointed out that the presence of the excavations would not affect the possibility of not building the canal, since contingent plans had been made to convert the excavations into fish hatcheries. Id. at 300. The significance of the contingency plans regarding the hatchery was that resources committed to making the excavations could be productively employed and not regarded as "lost" if an alternative to the original program were adopted, thus alleviating any potential pressure to complete the canal to prevent the loss. The existence of a sliding scale makes a precise application of the foreclosure of alternatives test extremely difficult.

75. By contrast, completion of the proposed highway segments in San Antonio Conservation Society, which also had no independent utility, would not render altemative routes to the expressway absolutely impossible, but highly improbable. See notes 72-73 supra and accompanying text.

76. It was for this reason that in Friends of the Earth v. Coleman the Ninth Circuit rejected the claim that obtaining the fill from the canal site so linked it with the highway project that both must be evaluated together. The court stated that the highway project involved no commitment of resources to the canal project, since the funds would have to be expended to obtain the fill anyway, and the canal site was the cheapest source. 513 F.2d 295, 300 (9th Cir. 1975).

If the capacity of a project is greater than that required for purely local demand, however, the excess capacity does represent a commitment of resources to completion of the broader program. See text accompanying notes 57-58 supra. Cf. No East-West Highway Comm. v. Whitaker, 403 F. Supp. 260 (D.N.H. 1975). 
The Second Circuit in its first decision in Conservation Society of Southern Vermont, Inc. v. Secretary of Transportation ${ }^{77}$ (Conservation Society I), held that despite a project's independent utility, it entailed an irretrievable commitment of resources to a broader program. In Conservation Society $I$ the court ordered the evaluation of the environmental impact of expressway development throughout a 280 mile corridor prior to construction of a twenty-seven mile segment of highway. ${ }^{78}$ While acknowledging that the segment had independent utility, the Second Circuit echoed the district court's concern over the irretrievable commitment of funds to local highway projects without evaluation of highway development along the entire corridor. ${ }^{79}$ The assertion that a project with independent utility entails an irretrievable commitment of resources to a larger program appears to be misguided, but the court alluded to an additional factor which provided support for its decision to enjoin construction of the highway segment. Construction of isolated segments of the expressway, the district court had observed, would induce traffic along the entire route, creating demand for completion of the entire program. ${ }^{80}$ Thus, despite the independent utility of the project enjoined in Conservation Society $I$, the coinpletion of several such projects would generate an impetus for the construction of the remaining segments of the program.

Conservation Society $I$ was vacated and remanded by the Supreme Court, ${ }^{81}$ and in Conservation Society II the Second Circuit reversed its earlier holding. ${ }^{82}$ Reasoning that since the project had independent utility it involved no irretrievable commitment of resources, the court concluded that no corridor impact statement was required. In so deciding, the circuit court apparently overlooked its earlier concern ${ }^{83}$ that pressure would be generated for completion of the expressway along the entire corridor. Also disregarded was the shift in cost/benefit analysis which occurs as early segments of a program are

77. 362 F. Supp. 627 (D. Vt. 1973), aff'd, 508 F.2d 927 (2d Cir. 1974), vacated sub nom. Coleman v. Conservation Soc'y of S. Vt., Inc., 96 S. Ct. 19 (1975), rev'd, 531 F.2d 637 (2d Cir. 1976).

78. 508 F.2d at $927,934-36$.

79. Id. at 935. Also crucial to the decision was the district court finding that construction of a superhighway through the three-state corridor was a long-range goal of the respective states and the federal government, acting in partnership. Id. at 934 . See notes 90-91 infra and accompanying text.

80. 362 F. Supp. at 636. Accord, Appalachian Mountain Club v. Brinegar, 394 F. Supp. 105, 119 (D.N.H. 1975).

81. 96 S. Ct. 19 (1975).

82. 531 F.2d 637 (2d Cir. 1976).

83. See text accompanying note 80 supra. 
completed: once a project is completed, only incremental cost is relevant in weighing the costs of the remainder of the program against its benefits, and completion of the program becomes more attractive. ${ }^{84}$

The pressure to complete subsequent projects and the shift in cost/benefit analysis which accompany a project entailing irreversible and irretrievable commitment of resources to a broader program reflect the true concern that completion of an early project will dictate or cause the environmental damage of a subsequent project. ${ }^{85}$ The arguable conclusion is that the analytical focus in determining the scope of an impact statement should shift to meet this broader concern more directly. ${ }^{86}$ A further conclusion which may be drawn is that although a finding of independent project utility is necessary to ensure that the impact statement is broad enough in scope, it is not sufficient; the inquiry must proceed further. A finding of independent utility guarantees that there will be no irretrievable commitment of resources; ${ }^{87}$ it does not guarantee, however, that there will be no pressure to complete subsequent projects or that there will be no shift in the cost/benefit ratio. Accordingly, while it is correct to conclude that a project which has no independent utility is too narrow to be evaluated separately, it is erroneous to conclude that a project's environmental effects can be adequately evaluated solely because it has independent utility. ${ }^{88}$

\section{Existence of a Program Plan}

An alternative approach adopted by a few courts, ${ }^{89}$ often in con-

84. See Scientists' Institute for Pub. Information, Inc. v. AEC, 481 F.2d 1079, 1089 n.43 (D.C. Cir. 1973); Rhode Island Comm. on Energy v. Government Services Administration, 397 F. Supp. 41, 61 (D.R.I. 1975).

85. Cf. Citizens Against the Destruction of Napa v. Lynn, 391 F. Supp. 1188, 1194 (N.D. Cal. 1975), in which the court employed what it called the "coercive effects" test, asking whether completion of a proposed project would coerce the completion of an additional project.

86. Such an approach is developed in the text accompanying note 118 infra.

87. See text accompanying note 76 supra. There is no irretrievable commitment of resources subject to the caveat discussed in note 76 supra, i.e., so long as project capacity does not exceed the local or independent demand.

88. See Citizens for Balanced Environment and Transp. v. Volpe, 503 F.2d 601, 606 (2d Cir. 1974) (Winter, J., dissenting), cert. denied, 96 S. Ct. 135 (1975); Appalachian Mountain Club v. Brinegar, 394 F. Supp. 105, 117 (D.N.H. 1975) ("The concepts of 'independent utility' or 'logical termini' are not talismans that truncate the natural scope of an EIS").

89. E.g., Sierra Club v. Morton, 514 F.2d 856 (D.C. Cir. 1975), cert. granted sub nom. Kleppe v. Sierra Club, 96 S. Ct. 722 (1976); Conservation Soc'y of S. Vt., Inc. v. Secretary of Transp., 508 F.2d 927 (2d Cir. 1974), vacated sub nom. Coleman v. Conservation Soc'y of S. Vt., Inc., 96 S. Ct. 19 (1975), rev'd, 531 F.2d 637 (2d Cir. 1976); No East-West Highway Comm. v. Whitaker, 403 F. Supp. 260 (D.N.H. 1975). 
junction with the commitment of resources and foreclosure of alternatives tests, is to look for activities by federal officials which might constitute major federal action. Confronted by the challenge that a project is too narrowly segmented, a court utilizing this approach would seek evidence that the project is part of a broader program consciously planned by federal officials. Convincing evidence of such a plan would dictate preparation of an impact statement on the overall program before the project could be completed.

The existence of a program plan was an important factor in the Second Circuit's decision to require a program impact statement in Conservation Society I. Critical to that holding was the lower court finding that completion of a limited access superhighway through Connecticut, Massachusetts, and Vermont was viewed by the respective state highway departments as a long-range goal. ${ }^{90}$ Despite the absence of a federal plan, the court found that federal officials had knowledge of the overall planning process and to a considerable extent worked in partnership with state officials. ${ }^{01}$ Relying on this evidence of a federal-state "partnership," the Second Circuit held that ordering a program-wide impact statement was justified because of the commitment of resources and foreclosure of alternatives involved in the project. ${ }^{22}$

In hight of the vacation of Conservation Society $I,{ }^{03}$ and the Supreme Court's accompanying admomition to reconsider the case in light of Aberdeen and Rockfish R.R. v. Students Challenging Regulatory Agency Procedures ${ }^{94}$ (SCRAP), the Second Circuit repudiated its earlier approach and reversed itself in Conservation Society ${ }{ }^{95}{ }^{95}$ Seizing upon the holding of SCRAP that a federal agency must prepare an impact statement at "the time at which it makes a recommendation or report on a proposal for federal action," out that there had been no finding of an "overall federal plan" by the

90. 362 F. Supp. 627,636 (D. Vt. 1973).

91. Id. The Second Circuit refused to disturb this finding by the lower court, asking only if ordering an impact statement on the highway over the entire 280 mile corridor was within the discretion of the judge. 508 F.2d at 934 .

92. 508 F.2d at 935. The approach of the Second Circuit in Conservation Society $I$ was followed by the District Court of New Hampshire in No East-West Highway Comm. v. Whitaker, 403 F. Supp. 260 (D.N.H. 1975). Finding a state plan and an "amorphous" federal goal of constructing an east-west highway across New Hampshire, the court held that NEPA would require an impact statement on the entire highway before further construction of any of the segments; however, the court withheld a decision on the merits because the case was not yet ripe. See note 135 infra.

93. Coleman v. Conservation Soc'y of S. Vt., Inc., 96 S. Ct. 19 (1975).

94. 422 U.S. 289 (1975).

95. 531 F.2d 637 (2d Cir. 1976).

96. 422 U.S. at 320 (emphasis in original). 
district court, ${ }^{97}$ and accordingly found no need for a corridor impact statement. $^{.8}$

Sierra Club v. Morton ${ }^{98}$ (Northern Great Plains), contains the most comprehensive treatment of the program plan approach to determining the scope of an impact statement. Concerned over the impending massive development of the Northern Great Plains, one of the world's richest coal basins, the Sierra Club and other groups sought an order requiring the Departments of the Interior, Agriculture, and the Army to prepare a comprehensive regional impact statement before granting any permits and licenses which would allow development of the area. ${ }^{100}$ The

97. $531 \mathrm{~F} .2 \mathrm{~d}$ at 639.

98. Id. Although the Supreme Court had remanded Conservation Society I for reconsideration in light of $S C R A P$ (a second ground for the vacation and remand was Pub. L. No. 94-83, 89 Stat. 424, legislatively overruling the rigid standard evolved by the Second Circuit for federal involvement in the preparation and drafting of impact statements), it is questionable whether the holding in SCRAP required the reversal of Conservation Society I. SCRAP grew out of an increase in railway freight rates which became effective in February, 1972. Plaintiff SCRAP charged that the underlying freight rates discriminated against recyclable material in favor of virgin materials, and that the increase further exacerbated the situation. After the Interstate Commerce Commission announced that it was studying the environmental effects of the underlying rate structure in a separate investigation, SCRAP sought an injunction to restrain the rate increase pending completion of such a comprehensive evaluation. The Supreme Court held that a comprehensive impact statement was not yet necessary, citing the following factors: the ICC had undertaken an evaluation of the entire rate structure in a separate proceeding; the rate increase was a general percentage increase, and thus facially neutral; and the ICC had broad discretion in deciding what issues to address in a general revenue proceeding. 422 U.S. at 325 . None of these factors was present in Conservation Society 1 . By contrast, it was unlikely that there would ever be a comprehensive evaluation of the development of Route 7 throughout its 280 mile corridor; each highway construction project, far from being facially nentral, had detrimental environmental consequences; and broad discretion comparable to that traditionally afforded the ICC was not involved.

A CEQ memorandum to the heads of agencies concerning the SCRAP case expresses the CEQ position that the decision is limited to its unique facts, and requires no general change in agency NEPA procedures. Council on Environmental Quality, Memorandum to the Heads of Agencies (Nov. 26, 1975), reprinted in Hearings on NEPA Oversight 246-47. Cf. Nolan, The National Environmental Policy Act After United States v. SCRAP: The Tinting Question and Substantive Review, 4 HoFSTRA L. Rev. 213, 243 (1976); Note, SCRAP II: No Excuse for NEPA Foot-Dragging, 5 ENv. L. REP. 10126, 10128 (1975) ("All aspects of the Supreme Court's reversal of the district court decision rest on the unique character of the ICC's 'general revenue proceeding'").

99. 514 F.2d 856 (D.C. Cir. 1975), cert. granted sub nom. Kleppe v. Sierra Club, 96 S. Ct. 772 (1976).

100. 514 F.2d at 867. Plaintiffs pointed to language in the CEQ Guidelines calling for a comprehensive impact statement "whenever a group of individual federal projects are related geographically, environmentally, or programmatically." 40 C.F.R. $\$$ $1500.6(d)(1)(1975)$. 
Court of Appeals for the District of Columbia Circuit first alluded to its earlier holding in SIPI ${ }^{101}$ that the cumulative effect of a series of federal actions can itself constitute a major federal action which requires evaluation in an impact statement, and then cast the issue as "whether to extend SIPI to require comprehensive impact statements in situations where the responsible agencies deny they are engaged in a broad program."102 Stating that the requirement for an impact statement cannot turn simply on whether the agency has denominated a series of activities a "prograin,"103 the court held that the government agencies had treated development of the region and issuance of leases in the region in such a way that their actions comprised, cumulatively, a regional program constituting major federal action. ${ }^{104}$ The court refused to order an impact statement, however. The case was remanded to the district court to allow the federal agencies to make a final decision on the role they would play in the region and to determine at what point the program would be ripe for evaluation. ${ }^{105}$

In his dissenting opinion, Judge MacKinnon took exception to the majority's reliance upon SIPI, pointing out that the crucial factor in both SIPI and Conservation Society $I$ was the "irretrievable commitment of resources beyond what was actually expended in an individual project."100 Judge MacKinnon was unable to find any sucl conmitment of resources in Northern Great Plains, viewing eacl development as "cssentially independent from developments elsewliere in the region." "107

The tension between the majority and the dissent in Northern Great Plains arose from the fact that the inajority found a major federal action in the form of regional planning, but failed to defime how this action had a significant effect on the environment. Since an impact statement is required only for actions significantly affecting the environ-

101. See notes 64-69 supra and accompanying text.

102. 514 F.2d at 872 .

103. Id. at 873 .

104. Id. at 875. The court cited four items as evidence that the federal defendants had treated their actions regionally: an effort to develop a comprehensive plan for regional development; recognition by responsible officials in various agencies of the need for comprehensive regional development; recognition of the need for cumulative study of environmental effects as a result of federal planning to date; and urging of cumulative environmental consideration of the area by the Environmental Protection Agency. Id. at 875-77 \& n.28.

105. Id. at $880-82$.

106. Id. at 887 (einphasis added). See notes $64-69,77-80$ supra and accompanying text.

107. 514 F.2d at 888. 
ment, ${ }^{108}$ a program statement should be required only if the program as a whole has an impact greater than that of the individual projects which comprise it. The only discussion of this critical point is in the footnote rejoinder to the dissent, which stated that a relationslip among developments within the region could be found in the irretrievable commitment of limited water supplies to each project allowed, and the cumulative effect of the population influx they would cause. ${ }^{109}$ It seems likely that the effects of each project within the region are interrelated, ${ }^{110}$ but the majority's gloss was clearly inadequate to establish this as a fact. ${ }^{111}$

108. 42 U.S.C. $\$ 4332(2)(C)(1970)$.

109. 514 F.2d at 877 n.28. Judge MacKinnon's reply was twofold: the population influx for each mine is an effect of that mine which must be evaluated in the impact statement for that mine; and there had been no showing that the contemplated strip mines had sufficient impact on regional water resources to foreclose alternatives. Id. at 889 n.12 (dissenting opinion of MacKinnon, J.). His population argument overlooked the fact that there may be synergistic effects of the cumulative influx for a number of mines, and also that if restricting population influx due to new mines is deemed desirable, it should be done programmatically, to achieve optimum allocation of manpower. His response to the commitment of scarce water resources assertion illustrated a basic defect of the majority opinion: a failure to articulate specific ways in which the impact of the entire program is greater than or different from the cumulative project impacts.

110. The Sierra Club, in opposing the Justice Department's petition for review by the Supreme Court, asserted that there are indeed such related effects at the regional level: "None of the basic regional issues underlying the past and proposed federal actions concerning coal development in the Northern Great Plains has ever been analyzed in any environmental impact statement." Examples of such basic regional issues were stated to be surface mining versus deep mining, transportation of coal, and allocation of scarce water resources. 6 BNA Environmental Rep. CURRent Developments 1382 (Dec. 12, 1975). See also Hearings on NEPA Oversight 174; SixTH ANNUAL REPORT OF THE CounctL on ENVIRoNMENTAL QuALITY 544-57 (1975).

Officials within the Interior Department acknowledge the interrelationships among projects which are geographically contiguous. Speaking of a compiex of actions around the Garrison Dam in North Dakota, Robert Jones of the Bureau of Land Management pointed out that

These projects are interrelated. One project in the area might have acceptable environmental consequences, but, if you have border-to-border projects all the way across you have a substantially different environmental situation. Hearings on NEPA Oversight 31 .

111. A similar failure to articulate how project effects are interrelated is evident in Cady v. Morton, 527 F.2d 786 (9th Cir. 1975). The Bureau of Indian Affairs had approved a lease by the Crow Tribe of coal rights to 30,000 acres of land for ten years or as long as coal could be produced in paying quantities. Instead of preparing an impact statement for the entire 30,000 acres, the Interior Department prepared a statement for the first mining plan submitted by the lessor, covering 770 acres of land for a five year period. Stating that the effects of a 30,000 acre mining project over twenty years or more differ significantly from the impact of a five year project covering only 770 acres, the Ninth Circuit held that an EIS was required for the approval of the overall twenty year mining project planned by the lessor, as well as for each miming project individually approved. Id. at 795 . What is missing from the opinion is any explanation of how the effects of the twenty year program differ from, or are cumulatively greater 
Because of this defect in its analytical framework, the majority was not convincing in its attempt to distinguish earlier cases which refused to order a program impact statement. ${ }^{12}$ This distinction was grounded on the assertion that the earlier cases had considered the propriety of an injunction against an individual project, ${ }^{113}$ and none had involved a direct challenge to the need for a regional statement, ${ }^{114}$ a proposition which the dissent, with good reason, called "a classic example of a distinction without a difference."115

Evident in Northern Great Plains is the primary defect of the program plan approach to determining the appropriate scope for an impact statement: the need for environmental evaluation does not turn upon the existence or non-existence of comprehensive planning. If the

than, the impacts of each separate mining plan. The only attempt at such an explanation is the conclusory statement that "the breadth and scope of the possible projects made possible by the Secretary's approval of the leases require the type of comprehensive study that NEPA mandates adequately to inform the Secretary of the possible environmental consequences of his approval." Id. The result is made even more anomalous by the court's holding that the impact statement prepared for the $\mathbf{7 7 0}$ acre tract was adequate, $i d$. at 796-98, and that development of the tract under the five year project could proceed. Id. at 798-99 n.12. However, if the 770 acre project statement is adequate, then that project must have no effects not considered therein. If this is so, there can be no need for a program statement (at least, not until an adequate project statement is prepared). Cf. note 113 infra.

112. See 514 F.2d at $878-79$ n.29. Of particular interest is the majority's treatment of Sierra Club v. Callaway (Wallisville Dam), 499 F.2d 982 (5th Cir. 1974); Sierra Club v. Stamm (Strawberry Aqueduct), 507 F.2d 788 (10th Cir. 1974); and Trout Unlimited v. Morton, 509 F.2d 1276 (9th Cir. 1974). (See notes 47-57 supra and accompanying text for discussion of these cases.) The majority pointed to the differing facts in each of the cases, and stated that each project challenged in these cases was found to have sufficient independent utility to warrant treating it separately from the larger program of which it was a part. 514 F.2d at 878 n.29. The majority offered no explanation why the facts of the cases serve to distinguish them. Independent utility is a most unsatisfactory distinction, for projects having independent utility may be combined to make up an overall program planned by federal officials, and the existence of such a federal plan or regional treatment was the basis for the court's holding that a comprehensive impact statement would be required in this case if the federal defendants continued to treat development regionally. Judge MacKinnon was highly critical of the majority treatment of these cases, finding them close factually to the case under consideration. Id. at 889.

113. The dissent seized upon this point, suggesting that the need for a regional or program impact statement could only be asserted in a challenge to a project statement, presumably on the theory that if a program statement is necessary, any project statement will be insufficient for its failure to consider the cumulative effects of all projects. Id. at 887. This seems to be an unnecessary limitation upon such suits, for considerable effort may go into a program before the first project impact statement is prepared, and by the time of a possible judicial determination that a program statement is necessary, delaying the entire program pending statement preparation may be extremely costly.

114. Id. at 878 n. 29 .

115. Id. at 889 . 
need for an impact statement were determined by the scope of federal planning, a reviewing court would be placed in a hopeless dilemmaeither to accept the agency's announced plan as the correct unit of environmental evaluation, or else to embark upon an effort to determine what should be the extent of federal planning, a role eschewed even by the Northern Great Plains court. ${ }^{110}$ If an impact statement must be prepared for the Nonthern Great Plains development as a whole, it is not because of the existence of a program plan at the federal level; rather it is because the effects of the component projects are related to one another in such a way that they can be adequately evaluated only at the program level. ${ }^{117}$ This suggests a more workable criterion for determining the adequacy of the scope of an impact statement: interrelatedness of the impacts of component projects.

\section{Toward a Broader ANalysis- THE INTERRELATIONSHIP OF IMPACTS}

Analysis thus far has shown the separate criteria developed by the courts to be inadequate guides to impact statement scope, and has indicated that reviewing courts too often tend to limit their examination to one or two factors, thereby neglecting important impacts of a project. This suggests that consideration of the appropriate scope of an impact statement must encompass a variety of factors, including the following: one effect of an early project may be to create pressure to complete the remaining projects, bringing on the effects of the later projects; ${ }^{118}$ completion of an early project may commit resources to the program, shifting the balance of costs and benefits, and again creating

116. Appellants claimed in Northern Great Plains that an impact statement must be filed if comprehensive planning by a federal agency should be underway, whether or not the agency had in fact undertaken such planning. The court refused to rule on the claim only because it held that the facts showed that regional development was contemplated by the defendants. 514 F.2d at 875 . The court acknowledged that requiring an impact statement whenever comprehensive planning should be underway creates practical difficulties, since an infinite number of plans are possible, and since several different plaintiffs might seek evaluation of inconsistent plans. Id. at 874-75. Cf. Brief for Petitioner at 46 n.37, Kleppe v. Sierra Club, 96 S. Ct. 772 (1976).

117. The Interior Department had prepared an impact statement to assess the impact of its coal program on a nationwide basis, Brief for Petitioners at 7 , Kleppe v. Sierra Club, 96 S. Ct. 772 (1976), as well as a regional impact statement upon coal mining within the Eastern Powder River Basin, id. at 9. The approach of the D.C. Circuit Court leaves open the question why these impact statements are inadequate, and why a statement is needed for the entire Northern Great Plains as well. Id. at 44 . That question can only be answered by exploring the relationship among the effects of all proposed mining projects throughout the region.

118. See text accompanying note 80 supra. 
an impetus for completion of the remaining projects; ${ }^{119}$ an early project may foreclose alternatives, increasing the probability that the effects of later projects will materialize; $;^{120}$ several projects may have a synergistic effect, creating a cumulative impact greater than the sum of their individual impacts; ${ }^{121}$ or, two or more projects may have a joint impact. ${ }^{122}$ Each factor is essentially one form of link or relationship which may exist between the impacts of two or more component projects of a proposed program. The factors may be examined together, therefore, under the rubric of interrelationship of impacts, and when considered as a group, they indicate the appropriate scope for an impact statement. Under this proposed analysis, a program impact statement must be prepared if the environmental effects of the component projects are related to one another in any way; if, however, the impacts of the projects are unrelated, no impact statement need be prepared.

The seeds of the analysis are present in the well-reasoned opinion of Judge Bownes of the District of New Hampshire in Appalachian Mountain Club v. Brinegar. ${ }^{123}$ In that case, environmentalists charged that the impact statement prepared for the Littleton-Waterford segment of an interstate highway near Francomia Notch State Park in New Hampshire failed to discuss adequately the effect of construction of the segment. ${ }^{124}$ Judge Bownes rejected the defendant's argument that assessment of effects beyond the vicinity of the segment was unnecessary since the segment was of independent utility:

The concepts of "independent utility" or "logical termini" are not talismans that truncate the natural scope of an [impact statement]. Reason mandates that the defendants assess the environmental harm, if any, that will occur to Franconia Notch if the Littleton-Waterford segment is completed. ${ }^{125}$

119. See text accompanying notes 67,84 supra.

120. See text accompanying note 68 supra.

121. E.g., Prince George's County v. Holloway, 404 F. Supp. 1181 (D.D.C. 1975), holding inadequate an impact statement on a proposed transfer of the Navy's oceanographic program to Bay St. Louis, Mississippi, for its failure to consider the cumulative impact of the Navy transfer, and proposed transfer of Army and NASA personnel to the same area.

122. See text accompanying notes 127-28 infra.

123. 394 F. Supp. 105 (D.N.H. 1975), continuing in effect an injunction imposed sub nom. Society for the Protection of N.F. Forests v. Brinegar, 381 F. Supp. 282 (D.N.H. 1974).

124. Interstate highway I-93 was completed up to Woodstock, N.H., less than three miles from the entrance to the Franconia Notch State Park. A segment of I-93 began one mile north of the state park, and ran to Littleton, N.H. The proposed segments, challenged in the instant case, would complete the highway from Littleton northward to connect with I-91.

125. 394 F. Supp. at 117. 
Limiting discussion of alternatives to the proposed Littleton-Waterford segment was also held to be inadequate, and the defendants were ordered to study alternatives which would not require construction of the remaining segment of the highway through the state park. Judge Bownes' decision was pervaded by an awareness of the interrelationship between the impact of the proposed segment and the impact of eventual completion of a final segment through Franconia Notch: construction of the proposed Littleton-Waterford segment would imcrease the deniand for completion of the segment through the Notch; it would increase traffic through the Notch, thus bringing about some of the eventual effects of the final segment even before construction of the final segment; and it would tend to foreclose alternatives to completion of the final segment. ${ }^{128}$

The imterrelationship of the impacts of two adjoining highway segments was the decisive factor in Ecology Center of Louisiana, Inc. v. Coleman, ${ }^{127}$ in which the Fifth Circuit overturned a summary judgment by the lower court that the highway project involved had been properly segmented. Unconvinced that each highway segment had independent utility, the court poimted to evidence that the environmental impacts of each segment would interrelate to affect the entire area, and remanded the case for decision whether the two segments of highway should be considered as a whole. ${ }^{128}$

Analysis of the interrelationship of impacts of component projects also serves to clarify the issues involved in Northern Great Plains. Clearly, making expenditures for the development of one mining project does not result in a commitment of those funds to the development of other mining projects. If, however, there are limited water resources in the region, scarce water supplies are irretrievably committed to each

126. Id. at $115,117,119$.

127. 515 F.2d 860 (5th Cir.), rev'g in part and remanding Ecology Center of La., Inc. v. Brinegar, 7 E.R.C. 1254 (E.D. La. 1975).

128. Id. at 870. The court failed to explain why this fact would necessitate a program statement. Presumably, an impact statement on both projects would be required because the effects of the two segments would combine to create a cumulative impact greater than the simple sum of the project effects. Also of interest is the statement that the court would leave for consideration of the district court on remand possible application of the doctriue it had announced in Sierra Club v. Callaway, 499 F.2d 982 (5th Cir. 1974), that the "practical necessities" of the situation may preclude preparation of a broader program statement. 515 F.2d at 870 n.12. Insofar as the "practical necessities" refer to the difficulty of obtaining sufficiently meaningful information to prepare an impact statement, the issue is really not the need for a program statement but the ripeness of preparation of a program statement. See text accompanying notes 134-35 infra. Surely, however, the practical necessities of a case cannot determine the need for a program statement, since that question turns upon the relatedness of the impacts of the component projects. 
mining project approved. This involves a corollary foreclosure of future alternative mining projects, since allocation of water resources to earlier projects precludes alternative projects which might be environmentally preferable. ${ }^{129}$ Finally, the population influx, degradation of air and water quality, and development of transportation arteries, all of which would result from the approval of a series of mining projects, will have a cumulative impact greater than the impacts of each project. Only in a comprehensive program impact statenient could sucl interrelationships be adequately explored, yet these issues were only touched upon in Northern Great Plains. ${ }^{130}$

A similar failure to explore the interrelationship of the effects of component projects is evident in Concerned About Trident v. Schlesinger, ${ }^{131}$ in which plaintiffs alleged a failure to prepare a program impact statement for the Navy "Trident System," an improved nuclear submarine/missile system. The Navy had decided to prepare an impact statement for each component of the system, for the nuclear propulsion system, and for the new support base at Bangor, Washington. The court demied the plaintiff's request for a declaration that the Navy must also prepare an impact statement for the system as a whole, and held that the program, as distinguished from its components, did not have any environmentally significant effects. ${ }^{132}$ Given the finding that the program as a whole had no effects apart from those of its components, the result was surely correct. It seems more likely, however, that a program as vast as the Trident program does involve foreclosure of alternatives, that completion of early phases of the program would generate considerable pressure for completion of later phases regardless of the environmental consequences, that early projects commit resources to the total program, and that a program impact statement is accordingly appropriate.

Analysis of the interrelationship of impacts of challenged projects is only the first step in resolution of litigation over the appropriate scope of an impact statement. Unless the effects of component projects are

129. 514 F.2d at 877 n.28.

130. Id. A recent study indicates that the secondary impacts of coal development in the Northern Great Plains will be the most significant effects of development within the region. Significant impacts foreseen include: population increases which are large compared to existing local populations; rapidly increasing demands for public services; effects upon Indian reservations; and an acceleration of the urbanization process already occurring in the region. SIXTH ANNUAL REPORT OF THE COUNCIL ON ENVIRONMENTAL QUALITY 136-37 (1975).

131. 400 F. Supp. 454 (D.D.C. 1975), appeal docketed, No.75-1515 (D.C. Cir.). 132. Id. at 490 . 
essentially unrelated, ${ }^{133}$ the court must decide if a program statement is to be prepared, and if so, whether ongoing projects should be enjoined pending its completion. Accordingly, the second step would be to consider the ripeness of the program in order to determine whether immediate preparation of a program impact statement would be appropriate or meaningful. The inquiry into ripeness for evaluation is the product of two competing concerns: the importance of considering environmental damage as early as possible, balanced against the futility of evaluation before sufficiently meaningful information is available. ${ }^{134}$ In an effort to reconcile these countervailing considerations, the SIPI court offered four factors which are appropriate in gauging ripeness in the inquiry at hand: how likely it is that the program will be feasible and how soon that will take place; how much information is available to predict the environmental effects, whether irretrievable commitments are being made and options foreclosed; and how severe the environmental effects are likely to be. ${ }^{\mathbf{1 3 5}}$ If preparation of an impact statement is held to be ripe, the third and final step would be to determine whether initial project activity should be halted pending completion of the program statement. This step would entail weighing the following factors to decide if the purposes of NEPA would best be served by enjoining project activity: the degree of interrelationship of the project impact with other program impacts; the extent of environmental detriment attendant to the project impact; the adequacy of environmental evaluation already performed upon the project; and the equities of the case. ${ }^{133}$

133. See, e.g., Nucleus of Chicago Homeowners Ass'n v. Lynn, 524 F.2d 225 (7th Cir. 1975), cert. denied, 96 S. Ct. 1462 (1976).

134. The SIPI court articulated the dilemma in the following way:

[W] are pulled in two directions. Statements must be written late enough in the development process to contain meaningful information, but they must be written early enough so that whatever information is contained can practically serve as an input into the decision making process. Scientists' Institute for Pub. Information, Inc. v. AEC, 481 F.2d 1079, 1094 (D.C. Cir. 1973).

135. Id. These four factors were again applied by the D.C. Circuit in the Northern Great Plains case. The court felt that two of the factors indicated that the program to develop the Great Plains was not sufficiently ripe for evaluation: it was impossible to tell how likely it was that the program would be implemented since the government agencies had not yet decided what role they would play in the region; and since the Department of Interior had imposed a moratorium on most licensing in the area irretrievable commitments of resources were largely being avoided. 514 F.2d at 880-81. A further example of application of the four factor test is found in No East-West Highway Counn., Inc. v. Whitaker, 403 F. Supp. 260 (D.N.H. 1975). As in Northern Great Plains, the court found the program not ripe for overall impact statement evaluation, since it was unclear whether the state would proceed with the construction of the east-west highway as alleged by plaintiffs.

136. See Aberdeen and Rockfish R.R. v. Students Challenging Regulatory Agency 
One effect of the three-step approach outlined above is to isolate the factors relevant to the scope of an impact statement and to assign the appropriate consequences to each factor. For example, while traditional equitable principles have no relevance to whether or not a program statement is required, the equities of the case should enter into a determination whether to enjoin a project pending completion of evaluation of the program as a whole. ${ }^{137}$ This approach has the advantage of reducing the importance of characterization of an activity by the responsible federal official, ${ }^{138}$ or of the funding of the program, and may in fact call for a reevaluation of the point at which a state project becomes "federalized" for purposes of NEPA. ${ }^{139}$

Procedures (SCRAP), 422 U.S. 289 (1975) (discussed in note 98 supra). While implicitly holding that an impact statement on the entire rate structure would be necessary, the Supreme Court found such an inquiry inappropriate at that time, because the challenged action had only an indirect environmental effect, and because the ICC was already in the process of preparing an impact statement. Cf. Nolan, note 98 supra, at $245-46$.

Sierra Club v. Callaway, 499 F.2d 982 (5th Cir. 1974) is another case in which a comprehensive environmental study was already underway, and in which the court refused to enjoin further activity on the challenged project. In a number of cases the courts have engaged in balancing the equities of the situation before deciding whether a project should be enjoined pending preparation of a program statement. See Cady v. Morton, 527 F.2d 786 (9th Cir. 1975). Compare Natural Resources Defense Council v. TVA, 367 F. Supp. 122 (E.D. Tenn. 1973), aff'd, 502 F.2d 852 (6th Cir. 1974), with Natural Resources Defense Council v. Morton, 388 F. Supp. 829 (D.D.C. 1974).

137. It has been suggested that in Wallisville Dam the Fifth Circuit looked to the equities of the case in making its determination that completion of an impact statement for the Trinity River Program was not necessary before commencing construction of the Wallisville Dam. Note, supra note 29, at 358-59. Cf. Sierra Club v. Morton, 514 F.2d 856, 878 n.29 (D.C. Cir. 1975); Environmental Defense Fund v. Armstrong, 356 F. Supp. 131,140 (N.D. Cal.), aff'd, 487 F.2d 814 (9th Cir. 1973).

138. It is odd that the D.C. Circuit should have placed such emphasis upon the existence of regional planning in the Northern Great Plains case. See notes 103-05 supra and accompanying text. It would seem incongruous to suggest that had the federal defendants made no effort to control the development of the area by regional planning, there would be a diminished need for environmental evaluation. Surely the need for program statements must turn upon the environmental effect or impact of the cumulative actions taken and their interrelatedness, and not solely upon the treatment of the activities chosen by federal officials.

139. Since many public works projects are undertaken as joint state-federal activities, there may be a question at what point the action has become sufficiently "federalized" to require compliance with NEPA. One of the more bizarre examples of the conundrums presented by this concept arose in the litigation over Route 7, a limited-access highway through Massachusetts, Connecticut and Vermont. In 1972 environmentalists were successful in winning an injunction against coustruction of a three-mile segment of Route 7 from Norwalk, Connecticut, north towards Danbury. Committee to Stop Route 7 v. Volpe, 346 F. Supp. 731 (D. Conn. 1972). The court held that since the planners wanted to connect Norwalk with Danbury, an impact statement had to be prepared for at least this length of highway. Id. at 740. The state response was to plan construction of the segment from Danbury north to New Milford using only state funds, holding in 


\section{CONCLUSION}

Under the analysis proposed in this Note, a court confronted by a challenge to the scope of an impact statement prepared for a proposed federal project should ask if the environmental effects of the project are so interrelated with the effects of later actions that the impact of the challenged project can only be adequately measured in a broader program statement. If such an interrelationship exists, the court should next determine the ripeness of the program for evaluation. Finally, it should judge the appropriateness of halting the challenged project pending completion of the program impact statement. By making explicit the concerns which have guided judicial determination of environmental challenges in the past, application of the interrelationship of impacts approach will elicit more relevant evidence from the parties to such cases and provide more adequate decisional criteria, thus furthering the purposes of NEPA by discouraging decisionmaking in "small but steady increments which perpetuate rather than avoid the recognized mistakes of previous decades."140

abeyance any further action on the enjoined segment from Danbury south to Norwalk. An attempt by environmental groups to prevent construction of the planned segment by extending the injunction granted in Committee to Stop Route 7 was denied by the court on two grounds: there was insufficient use of federal funds to federalize the project for NEPA purposes; and the project had an independent justification. Citizens for Balanced Environment and Transp. v. Volpe, 376 F. Supp. 806, 810, 813 (D. Conn.), aff'd, 503 F.2d 601 (2d Cir. 1974), cert. denied, 96 S. Ct. 135 (1975). The court recognized that the original decision in Committee to Stop Route 7 had not resolved the appropriate length for impact statement consideration, whether from Norwalk to Danbury, or all the way from Norwalk to New Milford (which would include the segment to be constructed exclusively with state funds). Despite the fact that construction of the challenged statefunded segment might subvert the environmental study mandated by the earlier case, the court refused to grant the injunction. $376 \mathrm{~F}$. Supp. at 809 n.1. The decision was affirmed on the funding ground in a brief opinion by the Second Circuit. 503 F.2d 601 (2d Cir. 1974). In a cogent dissent, Judge Winter pointed out that the lower court decision was inconsistent with the decision of the District Court of Vermont in Conservation Society $I$, ordering an impact statement upon the entire length of Route 7 , and suggested that the Second Circuit delay decision of the case until it had ruled on Conservation Society 1 . Id. at 602. When the Second Circuit later affirmed the lower court decision in Conservation Society I, it was careful to distinguish Citizens for Balanced Environment as turning solely on the lack of federal funding. 508 F.2d at $936 \mathrm{n} .43 \mathrm{a}$.

The net result was that under the state-federal funding distinction, the Second Circuit in the same year affirmed a decision allowing construction of a segment of Route 7 (which had arguably been enjoined in earlier litigation over a federally funded segment of the same highway) and also affirmed a lower court decision finding a state-federal partnership in completing Route 7 through a three-state 280 mile corridor and ordering preparation of an impact statement over the entire 280 mile length of highway. It would seem preferable to inquire into the effects of allowing completion of state funded segments upon later segments funded federally, and to ask if the projects are not so interrelated as to federalize the entire program.

140. S. REP. No. 296, 91 st Cong., 1st Sess. 5 (1969). 
